Agro-Science Journal of Tropical Agriculture, Food, Environment and Extension Volume 15 Number 2 May 2016 pp. $48-53$

ISSN 1119-7455

\title{
ECONOMICS OF CUCUMBER PRODUCTION IN RIVERS STATE, NIGERIA
}

\author{
Elum, Z.A., Etowa, E.B., and Ogonda, A.U. \\ Faculty of Agriculture, University of Port Harcourt, Rivers State, Nigeria \\ corresponding author's email: zelda.elum@uniport.edu.ng; zeldaforreal@yahoo.com
}

\begin{abstract}
Cucumbers are very easy to grow and make for a delicious treat. They are naturally low in calories, fat, cholesterol and sodium. The study aimed to determine the profitability of cucumber production in two local government areas of Rivers State. The specific objectives of the study included examining the socio-economic characteristics of cucumber producers, ascertaining the profit level and determinants of cucumber production in Rivers State as well as identifying the major constraints to cucumber production in the area. Purposive sampling technique was used as the farmers were sampled from selected communities that are known for cucumber production. Primary data was collected from randomly sampled farmers. The study employed descriptive statistics in examining the socio-economic characteristics of the cucumber farmers; gross profit margin analysis in examining profitability and the Garrett ranking technique in establishing the challenges faced by the farmers. From the study analysis, it was observed that the gross profit level of cucumber production was high $(\$ 1,909,292)$ and likewise the gross margin at 0.90. The study also revealed five major constraints affecting cucumber production in the study area and they included pest and disease attacks, poor funding and unfavourable climatic conditions. It is suggested that it is necessary for extension workers to create awareness among cucumber farmers on the best farming practices to deal with pest and diseases as well as cope with unfavourable climatic conditions.
\end{abstract}

Key words: Economics, cucumber, farmers, profitability, gross margin.

\section{INTRODUCTION}

Cucumber (Cucumis sativus L.) is a member of the cucurbitaceae and is an important vegetable crop (Eifediyi and Remison, 2010). Cucumbers are long, cylindrical green fruits that contain about $95 \%$ water and are for this reason often recommended as natural diuretics and helpful for body building. Globally, cucumber is considered a very important crop, however, in tropical Africa; its place has not been ranked because of its limited use (Wilcox et al., 2015). Cucumbers are classified as accessory fruits but are however perceived, prepared and eaten as vegetables. Cucumber is an annual deep-rooted crop with tendrils and hairy leaves. In typical commercial operations, cucumbers are grown in polythene-mulched beds with drip irrigation. Cucumbers are planted year round. They can be directly seeded or transplanted. The growing of vegetables like cucumber can result in high yield even on small farm land (Pozderec et al., 2010). Although vegetable production has been an ongoing practice as a source of livelihood for many people in Nigeria, it is a relatively recent addition to the diet of Nigerians. However, vegetable producers are faced with challenges that could be grouped into agronomic and socio-economic factors (Sabo and Zira, 2009).
For instance, many farmers are smallholders who are unable to adopt mechanized farming and therefore experience low farm productivity. The production of cucumbers in Rivers State is mostly carried out in Igwuruta, Omagwa, Oyigbo and Bunu/Ban-Ogoi (Songhai Rivers Development Initiative Farms) in Tai Local Government Area (LGA). Commercially, cucumber marketing in Rivers State is concentrated in Port Harcourt town markets, especially at the fruits gardens in the Trans-Amadi area of Port Harcourt.

This study became imperative because vegetables are important sources of food and income. Their cultivation plays significant role in the attainment of food security for a country (FAO, 2015). However, there is a high level of wastage in the production and marketing of vegetables due to inadequate cold storage facilities and lack of processing facilities (Mrema and Rolle, 2002). Post-harvest losses of perishables like vegetables pose serious challenges for the wellbeing of the citizens and endanger the livelihood of farmers involved in their production. In Nigeria, post-harvest losses of vegetables ranges from $20-40 \%$ because of inefficient harvesting techniques, inadequate processing and storage facilities thereby resulting in their unstable supply 
(Mrema and Rolle, 2002). Cucumber (Cucumis sativus $\mathrm{L}$.) if harvested and not stored immediately or properly, gets spoilt within a short time. Despite the nutritional and economic benefits cucumber provides to its consumers and producers, we posit that there is not much research on the profitability of its production in Rivers State. This study would thus, provide useful information to farmers involved in cucumber production in the state. Researchers will find the study useful for further research on cucumber production and marketing. It will also be a source of reference to students and policy makers. More so, the findings will add to existing literature on the economics of cucumber production. Equally important to note is that the production and marketing of cucumber is complex and challenging because of its peculiarities which include perish ability, seasonality, susceptibility to pest and diseases and standardization requirements. Other challenges include gender issues, labour cost, inadequate energy supply and aging farming population among others.

\section{MATERIALS AND METHODS}

The study was carried out in Rivers state and specifically in Igwuruta and Omagwa both in Ikwerre LGA, and in Oyigbo in Oyigbo LGA. Rivers State is one of the 36 states in Nigeria. Its capital is Port Harcourt. It is bounded on the south by the Atlantic Ocean, on the north by Imo and Abia States, to the east by Akwa Ibom State and to the west by Bayelsa and Delta States. It covers a total landmass of about $12,240 \mathrm{~km}^{2}$ with an estimated population of about $5,851,201$ people (Otto and Ukpere, 2014). The population of study was made up of all registered cucumber farmers in two purposively selected LGAs of Rivers State that were known for cucumber production in commercial scale. The major places in the state in which cucumber is grown on a commercial scale were first identified. These areas were Igwuruta, Omagwa and Oyigbo. Farmers were surveyed through a random sampling technique. 30 farmers from Igwuruta and 25 farmers from Omagwa were surveyed along with 30 farmers from Oyigbo. Thus, a total of 85 farmers were randomly surveyed from the selected areas. The collection of primary data was done with the aid of structured questionnaire using personal interviews. The study employed descriptive statistics such as means, frequencies and percentages to describe the socioeconomic characteristics of the farmers. Socioeconomic characteristics such as age, sex, education, family size, occupation, land size, experience, credit access, yield, seed source, fertilizer usage, irrigation are some of the factors that have been identified in the literature to affect cucumber production and marketing. Furthermore, a gross margin analysis was used in evaluating the profitability in production while the Garrett ranking technique by Garrett and Woodworth (1969) was used in establishing the challenges faced by farmers.

\section{Gross Margin Model}

Gross profit margin is defined in this study as the difference between revenue and variable costs directly associated with the crop production divided by revenue and expressed as a percentage. It is calculated as thus;

$$
\begin{aligned}
& \mathrm{GM}=\mathrm{TR}-\mathrm{TVC} \\
& \mathrm{GM}(\%)=\frac{\mathrm{TR}-\mathrm{TVC}}{\mathrm{TR}} \times 100 \\
& \mathrm{TR}=\mathrm{PQ} \\
& \mathrm{TVC}=\mathrm{C}_{1} \mathrm{X}_{1}+\mathrm{C}_{2} \mathrm{X}_{2}+\mathrm{C}_{3} \mathrm{X}_{3}+\mathrm{C}_{4} \mathrm{X}_{4}+\mathrm{C}_{5} \mathrm{X}_{5}
\end{aligned}
$$

where; $G M$ is the gross margin expressed in percentage, $T R$ is total revenue in naira, $T V C$ is total variable cost in naira, $P$ is price of cucumber per $\mathrm{kg}$ in naira and $Q$ is quantity of cucumber produced in $\mathrm{kg}$. $C_{1}$ to $C_{5}$ represent the unit cost in naira of the variable inputs: seeds, fertilizer, pesticide, labour and transport while $X_{1}$ to $X_{5}$ represent the respective quantities of these inputs in their standard units of measurements. Furthermore, multiple regression analysis was used to identify the determinants of the quantity of outputs of cucumber production in the study area. The double log form of the model was used for reason explained in the results section. The model was specified as:

$$
\begin{aligned}
\log Q= & \log \beta_{0}+\beta_{1} \log X_{1}+\beta_{2} \log X_{2}+ \\
& \beta_{3} \log X_{3}+\beta_{4} \log X_{4}+\ldots \\
& +\beta_{7} \log X_{7}+\beta_{8} \log X_{8}+e
\end{aligned}
$$

The variables in equation $\mathrm{V}$ are explained in Table 1. Regression diagnostics reported in next section were performed on the model and a priori expectations on the coefficients of $X_{1}$ to $X_{8}$ was positive. Decision rule was to reject null hypotheses at probability level of 0.05 (95\% confidence interval), otherwise accept.

\section{Garret Ranking Technique}

Constraints in cucumber production as identified in reviewed literature were presented to the farmers for ranking in the order of importance as it affects them. The ranks provided by the farmers were scored using the formula:

$$
\text { Percentage Position }=\frac{100\left(R_{i j}-0.5\right)}{N_{j}}
$$

where, $R_{i j}$ is the rank given to $i^{\text {th }}$ factor by the $j^{\text {th }}$ individual producer and $N_{j}$ is Number of factors ranked by the $j^{\text {th }}$ individual producer. 
Table 1: Definition of variables

\begin{tabular}{|c|c|c|}
\hline $\begin{array}{l}\text { Variable } \\
\text { label }\end{array}$ & $\begin{array}{l}\text { Variable } \\
\text { name }\end{array}$ & Variable definition \\
\hline $\mathrm{Q}$ & $\begin{array}{l}\text { Quantity } \\
\text { of output }\end{array}$ & Total production expressed in Naira \\
\hline $\mathrm{X}_{1}$ & Age & Number of farmer's years \\
\hline $\mathrm{X}_{2}$ & Education & $\begin{array}{l}\text { Categorized: } 0=\text { none, } 1=\text { primary, } \\
2=\text { secondary and } 3=\text { tertiary }\end{array}$ \\
\hline $\mathrm{X}_{3}$ & Family size & $\begin{array}{l}\text { Number of persons } \\
\text { in a farmer's family }\end{array}$ \\
\hline $\mathrm{X}_{4}$ & $\begin{array}{l}\text { Farming } \\
\text { experience }\end{array}$ & Number of years spent in farming \\
\hline $\mathrm{X}_{5}$ & Seed cost & $\begin{array}{l}\text { Cost of purchasing } \mathrm{s} \\
\text { eeds in Naira }\end{array}$ \\
\hline $\mathrm{X}_{6}$ & $\begin{array}{l}\text { Labour } \\
\text { charges }\end{array}$ & $\begin{array}{l}\text { Amount spent on paying } \\
\text { labour in Naira }\end{array}$ \\
\hline $\mathrm{X}_{7}$ & $\begin{array}{l}\text { Fertilizer } \\
\text { cost }\end{array}$ & $\begin{array}{l}\text { Cost of purchasing } \\
\text { fertilizers in Naira }\end{array}$ \\
\hline $\mathrm{X}_{8}$ & $\begin{array}{l}\text { Cost of } \\
\text { pesticide }\end{array}$ & $\begin{array}{l}\text { Amount spent on buying } \\
\text { pesticides in Naira }\end{array}$ \\
\hline $\log$ & Logarithm & $\begin{array}{l}\text { Logarithm of the respective } \\
\text { variables: } Q ; X_{1} \text { to } X_{8}\end{array}$ \\
\hline $\log \beta_{0}$ & $\begin{array}{l}\text { Log of Beta } \\
\text { intercept }\end{array}$ & $\begin{array}{l}\text { The logarithm of the intercept of } \\
\text { the regression model }\end{array}$ \\
\hline $\mathrm{B}_{1}-\beta_{8}$ & $\begin{array}{l}\text { Beta } \\
\text { coefficients }\end{array}$ & $\begin{array}{l}\text { Respective coefficients of the } \\
\text { logarithms of } X_{1} \text { to } X_{9}\end{array}$ \\
\hline $\mathrm{e}$ & Error term & $\begin{array}{l}\text { Stochastic term to capture } \\
\text { unexplained variation in } \mathrm{Q}\end{array}$ \\
\hline
\end{tabular}

\section{RESULTS AND DISCUSSION}

Socio-Economic Attributes of Cucumber Producers

The socio-economic attributes as regards the gender and educational status of the cucumber producers are summarized in Table 2. It can be seen from the table that $42.2 \%$ of the cucumber producers were males while the larger percentage (57.6) were females. The study also revealed that most $(62.4 \%)$ of the cucumber farmers attained secondary school certificate degrees, $17.6 \%$ of the farmers attained primary education, $18.8 \%$ had tertiary education and $1.2 \%$ had no formal education. Based on these results one may draw the following inferences: that cucumber production is likely a gender skewed occupation as majority of the farmers were women; most of the cucumber farmers were educated. Education is vital as it could enable quick capacity building in cucumber production. This view is in accord with the findings of Uwagboe et al. (2010) that the farmers' level of education could enhance their farming activities, level of awareness and level of receptivity of improved technologies. In addition, an educated labour force can easily adapt to the dynamic needs of a changing economy. More so, educated farmers are more amenable to risk taking and change than noneducated ones (Nwaru et al., 2006).

It is shown in Table 2 that most of the cucumber producers were females, and agrees with Wilcox et al. (2015) that more women are involved in agriculture. About $98.8 \%$ of the farmers had one form of formal education which indicates that the farmers were literate and could possibly find it easy
Table 2: Socio-economic characteristics of cucumber producers in the study area

\begin{tabular}{|c|c|c|c|c|c|}
\hline Characteristics & Mean & Min. & Max & $\begin{array}{c}\text { Freque- } \\
\text { ncy }\end{array}$ & $\begin{array}{c}\text { Percent- } \\
\text { age }\end{array}$ \\
\hline Gender & & 0 & 1 & & \\
\hline Male & & & & 36 & 42.4 \\
\hline Female & & & & 49 & 57.6 \\
\hline Educational status & & 0 & 3 & & \\
\hline None & & & & 1 & 1.2 \\
\hline Primary & & & & 15 & 17.6 \\
\hline Secondary & & & & 53 & 62.4 \\
\hline Tertiary & & & & 16 & 18.8 \\
\hline Age & 42.93 & 19 & 63 & & \\
\hline $19-30$ & & & & 11 & 12.9 \\
\hline $31-50$ & & & & 57 & 67.1 \\
\hline$\geq 51$ & & & & 17 & 20.0 \\
\hline Family size & 5.59 & 1 & 12 & & \\
\hline $1-5$ & & & & 43 & 50.6 \\
\hline $6-10$ & & & & 38 & 44.7 \\
\hline$\geq 11$ & & & & 4 & 4.7 \\
\hline Years of farming & 16.79 & 5 & 45 & & \\
\hline $1-10$ & & & & 24 & 28.2 \\
\hline $11-20$ & & & & 39 & 45.9 \\
\hline $21-30$ & & & & 14 & 16.5 \\
\hline$\geq 31$ & & & & 8 & 9.4 \\
\hline
\end{tabular}

Source: Field Survey (2015)

to adopt new technologies. However, Nwaru et al. (2006) observed that farmers would rely more on their farming experience for improved productivity rather than their educational attainment. Majority $(67 \%)$ of the farmers were in the age bracket of 31 to 50 and which indicates that the farmers are in their youthful and active years. In addition, it is shown that the average age of the farmers is 43 years and that the majority of the farmers had more than 11 years of farming experience, implying that the farmers have come of age and have had considerable knowledge of farming and it is expected that their wealth of experience would have improved over time. This is supported by Uwagboe et al. (2010) and Enete et al. (2002) studies that have shown that age and years of experience are important positive factors in farm work. This result also agrees with Busari et al. (2012) who noted that the years of farming experience and middle-age bracket of 41-60 years play vital roles in influencing farmers' production. This is because the number of years a farmer has spent in the farming business is an indication of the level of practical knowledge he may have acquired through experience on decisions taken and dealing with production, processing and marketing challenges. Increase in number of farming years would likely result in higher efficiency for the farmer by improving their level of productivity and income. However, it was noted in Nwaru et al. (2006), that the older a farmer became, the more his efficiency dropped. 
Profitability of Cucumber Production in the Area

The results of gross margin analysis are presented in Table 3, showing that the gross profit from cucumber production in the area is $\$ 1,909,292$ per annum. Based on the gross profit margin (90\%), about $\mathbf{N} 0.90$ is retained as gross profit on every naira of revenue and which could be used for other operational expenses. This gross profit which is realized after accounting for the costs of operating the business in a production season, indicate that in examining the first level of profitability, cucumber production is highly profitable in the study area. Table 3 shows that on average, a cucumber producer got total revenue of $2,112,000$ and incurred a total variable cost of \$202,708 which includes costs of transportation, seeds, fertilizer and pesticides. From the table, the average cost of land rent was $\$ 3,772$. The average quantity of cucumber sold per production season was 528 bags at an average price of $\$ 4,000$ per bag.

Determinants of Cucumber Production in the Area The results of the multiple regression analysis for the identification of the determinants of cucumber production are presented in Table 4. Four models were used and the estimates were evaluated for their performance using the standard economic criteria such as adjusted $\mathrm{R}^{2}$, F-calculated and number of significant variables. Among the four models, the $\log$-lin multiple regression model had the highest $\mathrm{R}^{2}$ value with high number of significant variables. The adjusted $\mathrm{R}^{2}$ estimate of the log-1 sin model indicated that $92.3 \%$ of the variation in cucumber production among the farmers can be explained by the independent variables included in the model. It was observed that three variables namely, farming experience, fertilizer and pesticide costs under the log-lin model showed positive and significant effects on cucumber revenue, all at $1 \%$ level. The regression
Table 3: Determination of profit level in cucumber production

\begin{tabular}{lcc}
\hline Items & $\begin{array}{c}\text { Average amount } \\
(\mathrm{N})\end{array}$ & $\begin{array}{c}\text { Percentage of } \\
\text { cost }\end{array}$ \\
\hline $\begin{array}{l}\text { Average amount of } \\
\text { cucumber sold in Naira }\end{array}$ & $2,112,000$ & \\
Average fixed cost & & \\
Rent & 23,772 & \\
Average variable cost & & \\
Transportation & 50,146 & 24.738 \\
Seeds & 42,329 & 20.882 \\
Hired labour & 72,047 & 35.542 \\
Fertilizer & 23,024 & 11.358 \\
Pesticides & 15,162 & 7.480 \\
Total variable cost (TVC) & 202,708 & 100.00 \\
Total revenue (TR) & $2,112,000$ & \\
Gross profit (TR -TVC) & $1,909,292$ & \\
Gross profit margin (\%) & 90.40 & \\
\hline Source: Field Surve (2015) &
\end{tabular}

Source: Field Survey (2015)

was considered a good fit to explain the relationship between the output and socio-economic factors of cucumber farmers. From the result of regression analysis, it can be inferred that a unit increase in the years of farming will result in a $0.4 \%$ increase in revenue. Likewise, a unit increase in expenditure on fertilizer will lead to a $0.001 \%$ increase in cucumber revenue. The F-value of 126.6 was significant at $1 \%$ and implies that all the independent variables have joint significant effects on the level of cucumber output. Increased output would invariably translate to increased profit, if the cost of operation is not increasing at the same rate. The result is in agreement with the submission of Badmus and Yekini (2011). Therefore, the null hypothesis which states that the value of output of cucumber farmers is not significantly influenced by their socio-economic characteristics was rejected.

Table 4: Regression estimates of the determinants of cucumber production

\begin{tabular}{|c|c|c|c|c|c|c|c|c|}
\hline \multirow{2}{*}{$\begin{array}{l}\text { Dependent Variable: } \\
\text { Output } \\
\text { Variable }\end{array}$} & \multicolumn{2}{|c|}{ Linear function } & \multicolumn{2}{|c|}{ Log-lin } & \multicolumn{2}{|c|}{ Double log } & \multicolumn{2}{|c|}{ Lin-log } \\
\hline & Coefficient & $P>|t|$ & Coefficient & $P>|t|$ & Coefficient & $P>|t|$ & Coefficient & $P>|t|$ \\
\hline Age & 4081733 & 0.14 & -0.001488 & 0.29 & -0.0000003 & 0.45 & 5740000 & 0.17 \\
\hline Education & 1880000 & 0.58 & 0.002827 & 0.87 & -0.0000001 & 0.66 & 216000 & 0.93 \\
\hline Family size & -7735472 & 0.42 & 0.004928 & 0.31 & -0.0000001 & 0.4 & -830000 & 0.58 \\
\hline Farming years & -4739278 & $0.10^{*}$ & 0.004757 & $0.00^{* * *}$ & 0.0000001 & 0.72 & -3480000 & 0.11 \\
\hline Seed cost & -54.21016 & 0.96 & 0.000003 & 0.81 & -0.0000001 & 0.68 & 405000 & 0.80 \\
\hline Labour cost & -1129.866 & 0.20 & 0.000005 & 0.27 & -0.0000001 & 0.57 & 1070000 & 0.64 \\
\hline Fertilizer & 24311.96 & $0.00^{* * *}$ & 0.000013 & $0.00^{* * *}$ & 1.000 & $0.00^{* * *}$ & 1280000 & $0.00^{* * *}$ \\
\hline Pesticide & 37221.12 & $0.00^{* * *}$ & 0.000269 & $0.00^{* * *}$ & 1.000 & $0.00^{* * *}$ & 1210000 & $0.00^{* * *}$ \\
\hline Constant & -7500000 & $0.00^{* * *}$ & 7.637403 & $0.00^{* * * *}$ & 0.0000013 & 0.37 & -1130000 & $0.00^{* * *}$ \\
\hline R-Squared & 0.8840 & & 0.9302 & & 1.000 & & 0.6699 & \\
\hline Adjusted R-Squared & 0.8718 & & 0.923 & & 1.000 & & 0.6352 & \\
\hline F-Value & 72.39 & & 126.64 & & - & & 19.28 & \\
\hline
\end{tabular}

***, ** and * indicate statistical significance at $0.01,0.05$ and 0.10 level respectively.

Source: Using E-Views Econometric Software (2014). Source: Field survey (2015) 
Table 5: Result of major constraints faced by cucumber producers in the study areas

\begin{tabular}{llccc}
\hline S/N & Constraints & $\begin{array}{l}\text { Total } \\
\text { score }\end{array}$ & $\begin{array}{c}\text { Mean } \\
\text { score }\end{array}$ & Rank \\
\hline 1 & Pest and disease attack & 6011 & 70.72 & I \\
2 & Poor funding & 5857 & 68.91 & II \\
3 & Poor climate conditions & 5201 & 61.19 & III \\
4 & $\begin{array}{l}\text { Inadequate extension } \\
\text { services }\end{array}$ & 4524 & 53.22 & IV \\
5 & Unavailability of land & 3323 & 39.09 & V \\
\hline Source: Field survey (2015) & & &
\end{tabular}

\section{Major Constraints Faced by Cucumber Producers in the Study Area}

The results from the Garret Ranking Technique are presented in Table 5. The technique identified five factors ordered from highest to lowest according to their limiting effects on cucumber production in the study areas. Pest and disease attacks were ranked as the first major constraints faced by the cucumber farmers with a garret score of 6011 points and a mean of 70.72. Further, poor funding was ranked as the second major constraint faced by the farmers with garret score of 5857 points and a mean of 68.91 which could be attributed to the fact that majority of the farmers had little or no other form of job to sustain themselves with their families. Poor climatic conditions came as the third major constraint with a garret score of 5201 points and a mean of 61.18. Studies (e.g., Elum et al., 2016) have shown strong correlation between agriculture and climatic conditions. The fourth major constraint was poor extension services being rendered to them. It had a garret score of 4524 and a mean of 53.22. The fifth major constraint was the issue of land unavailability/land tenure system. It had a Garret score of 3323 and a mean score of 39.09 .

\section{CONCLUSION}

This study sought to determine the profitability of cucumber production in the study areas. It sets out an example of cost and returns for cucumber growers. The findings of the study have been able to establish that the cucumber business is highly profitable among the farmers, with a gross profit of $\$ 1,909,292$ per production season; this is as a result of the low cost of inputs. From the study, it could be inferred that in the future, there is likely to be an increase in the production level of cucumber as more persons would engage in cucumber production because of its high profitability. More so, increasing wealth of knowledge gathered through the high average years of farming could have contributed to the observed high level of profitability. The study also revealed five major constraints faced by cucumber farmers in the study area according to their level of importance. It was deduced that awareness campaign for cucumber producers and extension workers is necessary in order to train them in the best farming practices to deal with pest and diseases as well as cope with changing climatic conditions. In addition, farmers need assistance in obtaining credit facilities for better production. The problem of land unavailability/land tenure system as a challenge can be controlled by the government through legal land fragmentation policies that can help to eliminate family or communal crisis. Furthermore, as observed, the level of extension services to the farmers was poor and this could hinder the adoption level of new innovations which will in turn lead to reduction in productivity and profitability. Finally, given the high level of profitability, studies on diverse utilizations and value addition in the cucumber business is necessary. Value addition is very essential as it will improve cucumber value chain, attract better prices and make the crop relevant as an export commodity.

\section{REFERENCES}

Akor, A., Ibitoye, S.J. and Ayoola, J.B. (2014). Analysis of socio-economic characteristics and profitability in cashew nut production in Kogi State, Nigeria. Int. J. Agric. Rural. Dev., 17 (2), 1739-1745

Badmus, M.A. and Yekini O.T. (2011). Economic analysis of exotic vegetable production among urban Fadama women farmers in Akinyele Local Government Area Oyo State, Nigeria. Int. J. Agric. Econ. Rural. Dev., 4(1), 19-24

Busari, A.O., Idris-Adeniyi, K.M. and Oyekale, J.O. (2013). Economic analysis of vegetable production by rural women in Iwo zone of Osun State, Nigeria. Greener J. Agric. Sci., 3(1), 006-011. $\mathrm{http//dx.doi.org/10.15580/GJAS.2013.1.110512231}$

Eifediyi, E.K., and Remison, S.U. (2010). Growth and yield of cucumber (Cucumis sativus L.) as influenced by farmyard manure and inorganic fertilize. J. Plant Breed. Crop Sci., 2 (7), 216-220

Elum, Z.A., Modise, D.M. and Marr, A. (2016). Farmer's perception of climate change and Responsive strategies in three selected provinces of South Africa. Clim. Risk Manag., http://dx.doi.org/10.1016/j.crm.2016.11.001

Enete, A.A., Nweke, F.I. and Tollens, E. (2002). Determinants of cassava cash income in female headed households of Africa. Q. J. Int. Agric., 41(3), 241-254

Engindeniz, S. and Gül, A. (2009). Economic analysis of soilless and soil-based greenhouse cucumber production in Turkey. Sci. Agric., 66 (5), 606-614

FAO (2015). Urban and Peri-urban Horticulture: Food and nutrition security. Food and Agriculture Organization of the United Nations.

http://www.fao.org/ag/agp/greenercities/en/whyuph/foodsecurity.html 
Garrett, H.E. and Woodworth, R.S. (1969). Statistics in Psychology and Education. Bombay, Vakils, Feffer and Simons Pvt. Ltd., p. 329

Grubben, G.J. and Denton, O. A. (2004). Plant resources of tropical Africa 2. Vegetable PROTA Foundation, Netherlands pp; 668

Hera, C. (1996). Role of inorganic fertilizers and their management practices. Fertil. Resour., 13:63-81

Mrema, C.G. and Rolle, S.R. (2002). Status of the Port Harcourt sector and its contribution to agricultural development and economic growth. Proc. $9^{\text {th }}$ JIRCAS Int. Symp. (JIRCAS'-AdditiontoAgricultural08). ValueIbaraki, Japan, pp: 13-20

Nwaru, J.C., Onyenweaku, C.E. and Nwosu, A.C. (2006). Stochastic frontier production functions and measurement of the technical efficiency of credit using and non-credit using arable crop farmers in Imo State of Nigeria. ASSET Ser. A., 6(2), 333-346

Otto, G. and Ukpere, W.I. (2014). Demoncracy and Development in Rivers State of Nigeria.Mediterr. J. Soc.Sci., 5(1), 243-248

Pozderec, S., Pazek, K. and Bavec, M. (2010). Economics of Peppers and Salad Cucumbers Production on an Open Land and in a Protected Space. Agric. Conspec. Sci., 75(3), 127-132
Sabo, E. and Zira, Y.D. (2009). Awareness and effectiveness of vegetable technology information packages by vegetable farmers in Adamawa State, Nigeria. Afr. J. Agric. Res., 4(2), 065-070

Schultheis, J.R. (2014). Fresh market production of cucumbers. Horticulture Information Leaflet, North Carolina State University. http://www.ces.ncsu.edu/depts/hort/hil/hil-14.html

Sinnadurai, S. (1992). Vegetable Cultivation. Asempa Publishers, Advent Press Accra. Tatliogu, T. (1997). Cucumber (Cucumis sativus L). In: Kailor, G and Bo Bergn, (eds.), Genetic improvement of vegetable crops (pp.197-227). Oxford Pergamon Press

Uwagboe, E.O., Ndagi, I., Agbongiarhuoyi, A.E., Adebiyi, S. and Aigbekaen, E.O. (2010). Assessment of insect pest and disease control by cocoa farmers in relation to their income in Kwara State, Nigeria. Middle East J. sci. Res., 6(2), 147-151.

Wehner, T.C. and Gunner, N. (2004). Growth stage, flowering pattern, yield and harvest date prediction of four types of cucumber tested at 10 planting rates. In. McGreight, J.D. and Ryder, E.J. (eds.), Proc. XXVI $I H C$ - Adv. in Vegetable Breeding, ISHS Acta. Hort.

Wilcox, G.I., Offor, U. S. and Omojola, J.T. (2015). Profitability of cucumber (Cucumis sativa $\mathrm{L}$ ) production in Tai Local Government Area of Rivers State, Nigeria. J. Adv. Stud. Agric. Biol. Environ. Sci., 2(3), 1-6 